\title{
Variability of elastic properties of chiral monoclinic tubes under extension and torsion
}

\author{
M. A. Volkov , V. A. Gorodtsov, D. S. Lisovenko \\ †volkovmikhl@gmail.com \\ Ishlinsky Institute for Problems in Mechanics RAS, 101/1 Vernadskii Av., Moscow, 119526, Russia
}

Based on the known solutions of the problems of extension and torsion of cylindrically anisotropic chiral tubes, the analysis of variability of the Young's modulus, Poisson's ratios and torsional stiffness of monoclinic crystalline tubes was carried out using known experimental values of the compliance coefficients of the crystals. The extreme values of Young's modulus and torsional stiffness were determined and their variability was studied. It was shown that chirality had a significant effect on the values of the elastic characteristics of tubes made from monoclinic crystals. Thin-walled tubes (the ratio of the external and internal radii of about one), which had a negative Poisson's ratio, were identified. The largest negative values of Poisson's ratio among all the analysed tubes were achieved for tubes from $\mathrm{LaNbO}_{4}$ and $\mathrm{CsH}_{2} \mathrm{PO}_{4}$ crystals. Due to the change in the ratio of the radii and the chirality, the Young's modulus and the torsional stiffness of such tubes were changed in several times, and their Poisson's ratios could change by several units. Angular Poisson's ratio could reach the value of -6.5 on the inner surface of a tube from $\mathrm{CsH}_{2} \mathrm{PO}_{4}$ crystal. The $\mathrm{LaNbO}_{4}$ and $\mathrm{CsH}_{2} \mathrm{PO}_{4}$ crystals also had large negative values of Poisson's ratios in the case of rectilinear anisotropy, which were significantly different from the Poisson's ratio for isotropic materials.

Keywords: auxetics, chirality, nanotubes, monoclinic crystals, Poisson's ratio.

УДК: 539.32

\section{Изменчивость упругих характеристик моноклинных хиральных трубок при растяжении и кручении}

\author{
Волков М. А. ${ }^{\dagger}$, Городцов В. А., Лисовенко Д.С. \\ Институт проблем механики им. А. Ю. Ишлинского РАН, пр. Вернадского, 101/1, Москва, 119526, Россия
}

На основе известных решений задач растяжения и кручения цилиндрически-анизотропных хиральных трубок проведен анализ изменчивости модуля Юнга, коэффициентов Пуассона и крутильной жесткости трубок из моноклинных кристаллов с использованием известных экспериментальных значений коэффициентов податливости кристаллов. Определены экстремальные значения модуля Юнга и крутильной жесткости и изучена их изменчивость. Показано, что хиральность оказывает существенное влияние на величины упругих характеристик трубок из моноклинных кристаллов. Выявлены тонкостенные трубки (отношение внешнего радиуса к внутреннему близко к единице) с отрицательным коэффициентом Пуассона. Среди всех проанализированных трубок отрицательные коэффициенты Пуассона наибольшей величины достигаются у трубок из кристаллов $\mathrm{LaNbO}_{4}$ и $\mathrm{CsH}_{2} \mathrm{PO}_{4}$. За счет изменения отношения радиусов и хиральности модуль Юнга и крутильная жесткость таких трубок изменяется в несколько раз, а их коэффициент Пуассона может изменяться на несколько единиц. На внутренней поверхности трубки из кристалла $\mathrm{CsH}_{2} \mathrm{PO}_{4}$ угловой коэффициент Пуассона может достигать -6.5. Кристаллы $\mathrm{LaNbO}_{4}$ и $\mathrm{CsH}_{2} \mathrm{PO}_{4}$ при прямолинейной анизотропии также имеют большие отрицательные значения коэффициента Пуассона, значительно отличающиеся от коэффициента Пуассона изотропных материалов.

Ключевые слова: ауксетики, хиральность, нанотрубки, моноклинные кристаллы, коэффициент Пуассона. 


\section{Introduction}

Recently, more and more attention has been paid to the study of the properties of materials with anomalous mechanical behaviour. These include materials with a negative Poisson's ratio (auxetics). For the first time the existence of such materials was reported in the monograph by Love [1], where it was stated that iron pyrite $\left(\mathrm{FeS}_{2}\right)$ has a Poisson's ratio of -0.14 . There are two most discussed types of materials with a negative Poisson's ratio: metamaterials [2-4] and crystals [5-9]. Analysis of the known experimental data on the elastic coefficients of crystals [10] showed that auxetic behaviour takes place in crystals of all crystalline systems. Poisson's ratio has negative values for tubes from different crystals. Estimates of the Poisson's ratios of cylindrically anisotropic nanotubes from cubic crystals show that Poisson's ratios can take negative values in almost all tubes of known cubic crystals [11]. A similar analysis was also performed for chiral tubes from hexagonal [12], rhombohedral [12], tetragonal [13], and orthorhombic [14] crystals. The analysis showed that the number of cylindrically anisotropic tubes with negative Poisson's ratio exceeded the number of auxetic crystals, and the absolute value of the Poisson's ratio of some tubes was also larger. Later in this letter we discuss the variability of the Poisson's ratio of tubes made from monoclinic crystals, some of which have a significant negative Poisson's ratio in the case of rectilinear anisotropy $[7,8,15]$.

\section{Radial non-uniform extension and torsion of chiral monoclinic tubes}

Tubes can be obtained by rolling-up thin crystalline plates. This is demonstrated in [16,17] for many various crystals. The directions of the crystallographic axes in the plate may differ from the directions of its faces by an angle a (Fig. 1).

The tube obtained by rolling-up such a plate is chiral. The cylindrically anisotropic hollow rod model was used to describe the mechanical behaviour of the tube. It is assumed that there is a local correspondence between the bases of the cylindrical and crystallographic coordinate systems $1^{\prime} \rightarrow z$, $2^{\prime} \rightarrow-\varphi, 3^{\prime} \rightarrow r$. The surfaces of the tube are free from stress. The integral torque $M_{z}$ and the tensile load $P_{z}$ are set at the ends of the tube. We assume that the solution of problems of tube deformations does not depend on the angular and longitudinal coordinates. Then the radially inhomogeneous solutions of the problems of extension and torsion of chiral monoclinic tubes completely coincide with the solutions of such problems for chiral tubes from orthorhombic crystals, obtained earlier in [14]. Using these solutions, the dependences of Young's modulus $E$, radial Poisson's ratio $v_{r z}$ and angular Poisson's ratio $v_{\varphi z}$, characterizing the tube deformations in the radial and angular directions, respectively, and torsional stiffness $C$ for chiral monoclinic tubes, were determined.

$$
\begin{gathered}
E=\frac{1}{t_{11}}-a_{1} \frac{t_{12}+t_{13}}{t_{11}}+\frac{2}{3} \Lambda\left(\frac{s_{16}^{\prime}}{s_{66}^{\prime} t_{11}}-a_{2} \frac{2 t_{12}+t_{13}}{t_{11}}\right) \frac{\rho^{3}-1}{\rho^{2}-1}- \\
-2 \sum_{ \pm} \frac{t_{13}+t_{12}\left(1+\lambda_{ \pm}\right)}{t_{11}} \frac{a_{1}\left(\rho^{\lambda_{\mp}}-1\right)+\Lambda a_{2}\left(\rho^{\lambda_{\mp}}-\rho\right)}{\left(\rho^{2}-1\right)\left(\rho^{\lambda_{ \pm}}-\rho^{\lambda_{\mp}}\right)} \frac{\rho^{\lambda_{ \pm}+2}-1}{\lambda_{ \pm}+2} .
\end{gathered}
$$

$$
\begin{aligned}
& -v_{r z}=\frac{t_{13}}{t_{11}}+a_{1}\left(t_{23}+t_{33}-t_{13} \frac{t_{12}+t_{13}}{t_{11}}\right)+ \\
& +\Lambda\left[\frac{s_{16}^{\prime} t_{13}}{s_{66}^{\prime} t_{11}}-\frac{s_{36}^{\prime}}{s_{66}^{\prime}}+a_{2}\left(2 t_{23}+t_{33}-t_{13} \frac{2 t_{12}+t_{13}}{t_{11}}\right)\right]\left(\frac{r}{r_{0}}\right)+ \\
& +\sum_{ \pm}\left[t_{33}-\frac{t_{13}^{2}}{t_{11}}+\left(t_{23}-\frac{t_{12} t_{13}}{t_{11}}\right)\left(1+\lambda_{ \pm}\right)\right] \times \\
& \times \frac{a_{1}\left(\rho^{\lambda_{\mp}}-1\right)+\Lambda a_{2}\left(\rho^{\lambda_{\mp}}-\rho\right)}{\rho^{\lambda_{ \pm}}-\rho^{\lambda_{\mp}}}\left(\frac{r}{r_{0}}\right)^{\lambda_{ \pm}}, \\
& -v_{\varphi z}=\frac{t_{12}}{t_{11}}+a_{1}\left(t_{23}+t_{22}-t_{12} \frac{t_{12}+t_{13}}{t_{11}}\right)+ \\
& +\Lambda\left[\frac{s_{13}^{\prime} t_{12}}{s_{66}^{\prime} t_{11}}-\frac{s_{26}^{\prime}}{s_{66}^{\prime}}+a_{2}\left(2 t_{22}+t_{23}-t_{23} \frac{2 t_{12}+t_{13}}{t_{11}}\right)\right]\left(\frac{r}{r_{0}}\right)+ \\
& +\sum_{ \pm}\left[t_{23}-\frac{t_{12} t_{13}}{t_{11}}+\left(t_{23}-\frac{t_{12}^{2}}{t_{11}}\right)\left(1+\lambda_{ \pm}\right)\right] \times \\
& \times \frac{a_{1}\left(\rho^{\lambda_{\mp}}-1\right)+\Lambda a_{2}\left(\rho^{\lambda_{\mp}}-\rho\right)}{\rho^{\lambda_{ \pm}}-\rho^{\lambda_{\mp}}}\left(\frac{r}{r_{0}}\right)^{\lambda_{ \pm}} \text {. } \\
& C=\frac{2 \pi}{s_{66}^{\prime}} r_{0}^{4}\left\{\Gamma\left[\frac{s_{16}^{\prime}}{t_{11}}+a_{1}\left(s_{26}^{\prime}+s_{36}^{\prime}-s_{16}^{\prime} \frac{t_{12}+t_{13}}{t_{11}}\right)\right]\right\} \frac{\rho^{3}-1}{3}+ \\
& +\left[1+\frac{s_{16}^{\prime 2}}{s_{66}^{\prime} t_{11}}+a_{2}\left(s_{36}^{\prime}+s_{26}^{\prime}-s_{16}^{\prime} \frac{t_{13}+2 t_{12}}{t_{11}}\right)\right] \frac{\rho^{4}-1}{4}+ \\
& +\left(\sum_{ \pm}\left[s_{36}^{\prime}-s^{\prime}{ }_{16} \frac{t_{13}}{t_{11}}+\left(s_{26}^{\prime}-s^{\prime}{ }_{16} \frac{t_{12}}{t_{11}}\right)\left(1+\lambda_{ \pm}\right)\right] \Omega_{ \pm} \frac{\rho^{\lambda_{ \pm}+3}-1}{\lambda_{ \pm}+3}\right)
\end{aligned}
$$

Here $s_{i j}^{\prime}$ are the compliance coefficients in the coordinate system rotated by the chiral angle $\alpha ; \rho$ is the thickness parameter equal to the ratio of the outer radius of the tube $R_{0}$ to the inner $r_{0}\left(\rho=R_{0} / r_{0}\right) ; t_{i j}, a_{1}, a_{2}, \lambda_{+}, \lambda_{-}$are coefficients depending on the compliance coefficients [14]; $\Gamma, \Lambda, \Omega_{+}, \Omega$ are coefficients depending on the thickness parameter and the compliance coefficients [14]; $r$ is the radial coordinate. Expressions (1)-(4) are functions of the chiral angle $a$ with period $\pi$.

The analysis of the variability of expressions (1)-(4) for 70 tubes was carried out using the values of the compliance

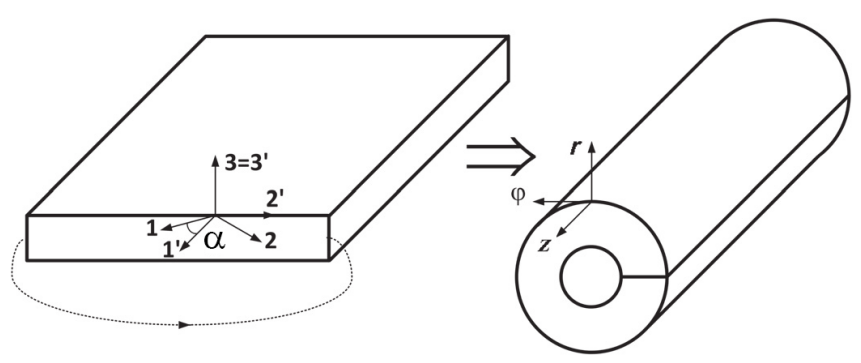

Fig. 1. Rolling-up the crystalline plate to the tube. 
coefficients from the handbook [10]. It was found that Young's moduli of 35 tubes varied by more than 2 times at $1.01 \leq \rho \leq 10$ and $0 \leq \alpha \leq \pi / 2$. Most of them have $E_{\min }<20 \mathrm{GPa}$. Table 1 summarizes the extreme values of the Young's modulus $\left(E_{\max }\right.$ and $\left.E_{\min }\right)$ of the tubes with the highest $E_{\max } / E_{\min }$ ratios. For all tubes, the minimum values are achieved at $\rho=1.01$, and the maximum values at $\rho=10$. The Young's modulus varies greatly for tubes from $\mathrm{LaNbO}_{4}, \mathrm{CsH}_{2} \mathrm{PO}_{4}$ and $\mathrm{SiO}_{2}$ (coesite). The Young's modulus of the first and the second tubes increases by 25 (Fig. $2 \mathrm{a}$ ) and 6.93 (Fig. 2 b) times in the selected range, respectively. The coesite $\left(\mathrm{SiO}_{2}\right)$ tube (Fig. 2c) has the greatest variability of the Young's modulus in values: $E_{\min }=88 \mathrm{GPa}, E_{\max }=202 \mathrm{GPa}$.

Many monoclinic crystal tubes are auxetic. Radial Poisson's ratio $v_{r z}$ has negative values for 40 of 70 tubes and the angular one $v_{\varphi z}$ for 30 tubes of 70 . Thin-walled $(\rho-1<<1)$ auxetic tubes are listed in Tables 2 and 3 for the cases $\alpha=0$ and $\alpha=\pi / 2$, respectively. Among non-chiral tubes $(\alpha=0)$ there are two tubes, each of which has either $v_{r z}$ or $v_{\varphi z}$ less than zero. For $\alpha=\pi / 2, v_{r z}$ is negative for four tubes, and $v_{\varphi z}$ for two tubes. Tables 2 and 3 also show the critical values of the thickness parameter, for which the Poisson's ratio equals zero. Among the chiral monoclinic tubes, tubes from $\mathrm{LaNbO}_{4}$ and $\mathrm{CsH}_{2} \mathrm{PO}_{4}$ crystals have the greatest variability of Poisson's ratios (Fig. 3). Both tubes are characterized by relatively small variability of $v_{r z}$ and $v_{\varphi z}$ on the outer surface (Fig. $3 \mathrm{~b}, \mathrm{~d}$ ), while their values on the inner surface can vary by several units (Fig. $3 \mathrm{a}, \mathrm{c}$ ). On the outer surface at $\rho=1.01$ both Poisson's ratios of the $\mathrm{CsH}_{2} \mathrm{PO}_{4}$ tube vary greatly with the chiral angle: $v_{r z}$ from -1.31 to 1.72 , and $v_{\varphi z}$ from -1.79 to 2.11 , which significantly exceeds the limit of $-1 \leq v \leq 0.5$. The values of the radial and

Table 1. Extreme values of the Young's modulus of some chiral tubes from monoclinic crystals when $1.01 \leq \rho \leq 10$ and $0 \leq \alpha \leq \pi / 2$.

\begin{tabular}{|c|c|c|}
\hline Tube & $E_{\text {min }}, \mathrm{GPa}$ & $E_{\max }, \mathrm{GPa}$ \\
\hline $\mathrm{NaAlSi} \mathrm{O}_{8}$ & 55.7 & 112 \\
\hline $\mathrm{CsD}\left(\mathrm{SeO}_{3}\right)$ & 7.14 & 18.0 \\
\hline $\mathrm{CsH}_{2} \mathrm{PO}_{4}$ & 0.55 & 14.4 \\
\hline $\mathrm{SiO}_{2}$ (coesite) & 88.5 & 202 \\
\hline Durene & 2.84 & 15.1 \\
\hline$(\mathrm{Ba}, \mathrm{K}) \mathrm{Al}_{2} \mathrm{Si}_{12} \mathrm{O}_{8}$ & 42.0 & 139 \\
\hline $\mathrm{LaNbO}_{4}$ & 15.0 & 104 \\
\hline $\mathrm{KHCO}_{3}$ & 7.19 & 38.0 \\
\hline $\mathrm{Na}_{2} \mathrm{~S}_{2} \mathrm{O}_{3} \cdot 5 \mathrm{H}_{2} \mathrm{O}$ & 5.95 & 20.9 \\
\hline
\end{tabular}

angular Poisson's ratios vary from 1.14 to 2.12 and from -1.12 to -0.26 , respectively, for the thin-walled $\mathrm{LaNbO}_{4}$ tube. Both Poisson's ratios vary significantly with the thickness parameter and chiral angle on the inner surface of the tube. The radial Poisson's ratio of the thick-walled $(\rho=10)$ tube from $\mathrm{CsH}_{2} \mathrm{PO}_{4}$ on the inner surface varies from -6.52 to 1.43 , and the angular Poisson's ratio from 3.02 to 10.2. For the thick-walled $\mathrm{LaNbO}_{4}$ tube the values of $v_{r z}$ or $v_{\varphi z}$ vary from 3.33 to 7.89 and -5.76 to 3.20 , respectively. $\mathrm{A}^{\varphi z}$ tube in which both Poisson's ratios have negative values has not been detected.

Tubes with large variability of relative torsional stiffness $\mathrm{C} / \mathrm{C}_{0}$ (ratio of torsional stiffness to torsional stiffness at zero chirality angle) were determined. More than twice $C / C_{0}$ varies for 14 tubes. Extreme values of the relative torsional stiffness of some chiral monoclinic tubes are presented in Table 4 for the range $1.01 \leq \rho \leq 10$ and $0 \leq \alpha \leq \pi / 2$. Fig. 4 shows the $C / C_{0}$ dependences for tubes made of $\mathrm{C}_{12} \mathrm{H}_{10}$ (Fig. 4 a), $\mathrm{C}_{6} \mathrm{H}_{14} \mathrm{~N}_{2} \mathrm{O}_{6}$ (Fig. 4 b) and $\mathrm{Na}_{2} \mathrm{~S}_{2} \mathrm{O}_{3} \cdot 5 \mathrm{H}_{2} \mathrm{O}$ crystals (Fig. 4c). The first two tubes illustrate the typical behaviour of the relative torsional stiffness of

Table 2. Thin-walled auxetic tubes from monoclinic crystals when $\alpha=0$. Auxetic tubes $\rho<2$.

\begin{tabular}{|c|c|c|c|c|c|c|c|}
\hline \multirow{2}{*}{ Tube } & \multicolumn{2}{|c|}{$v_{r z}$} & $v_{\varphi z}$ & \multicolumn{2}{|c|}{$\rho_{c r}$ at $v_{r z}$} & \multicolumn{2}{c|}{$\rho_{c r}$ at $v_{\varphi z}$} \\
\cline { 2 - 7 } & \multicolumn{2}{|c|}{$\rho-1<<1$} & $r=r_{0}$ & $r=R_{0}$ & $r=r_{0}$ & $r=R_{0}$ \\
\hline $\mathrm{C}_{12} \mathrm{H}_{10}$ & -0.07 & 0.65 & - & 1.71 & - & - \\
\hline $\mathrm{CsD}\left(\mathrm{SeO}_{3}\right)$ & -0.15 & 0.82 & - & 1.67 & - & - \\
\hline $\mathrm{CsH}_{2} \mathrm{PO}_{4}$ & 0.64 & 0.25 & - & - & 1.50 & - \\
\hline$\beta_{-} \mathrm{F}_{6} \mathrm{H}_{4} \mathrm{~F}_{6}$ & 1.01 & -0.14 & - & - & - & 1.29 \\
\hline $\mathrm{LaNbO}_{4}$ & 1.42 & -0.26 & - & - & - & 1.41 \\
\hline
\end{tabular}

Table 3. Thin-walled auxetic tubes from monoclinic crystals when $\alpha=\pi / 2$. Auxetic tubes $\rho<2$.

\begin{tabular}{|c|c|c|c|c|c|c|c|}
\hline \multirow{2}{*}{ Tube } & \multicolumn{2}{|c|}{$v_{r z}$} & $v_{\varphi z}$ & \multicolumn{2}{|c|}{$\rho_{c r}$ at $v_{r z}$} & \multicolumn{2}{c|}{$\rho_{c r}$ at $v_{\varphi z}$} \\
\cline { 2 - 7 } & \multicolumn{2}{|c}{$\rho-1<<1$} & $r=r_{0}$ & $r=R_{0}$ & $r=r_{0}$ & $r=R_{0}$ \\
\hline $\mathrm{A}-\mathrm{TCNB}$ & -0.25 & 0.38 & - & - & - & - \\
\hline $\mathrm{CsH}_{2} \mathrm{PO}_{4}$ & -1.35 & 2.14 & - & 78.8 & - & - \\
\hline $\begin{array}{c}\text { Feldspar: } \\
\text { Plagioclase, } \\
9 \text { (Albite) }\end{array}$ & -0.07 & 0.31 & - & - & - & - \\
\hline$\beta_{6} \mathrm{~F}_{6} \mathrm{H}_{4} \mathrm{~F}_{6}$ & 0.84 & -0.34 & - & - & - & 2.14 \\
\hline $\mathrm{LaNbO}_{4}$ & 2.10 & -1.16 & - & - & - & 3.22 \\
\hline $\mathrm{K}_{2} \mathrm{Co}(\mathrm{CN})_{6}$ & -0.05 & 0.14 & - & - & - & - \\
\hline
\end{tabular}
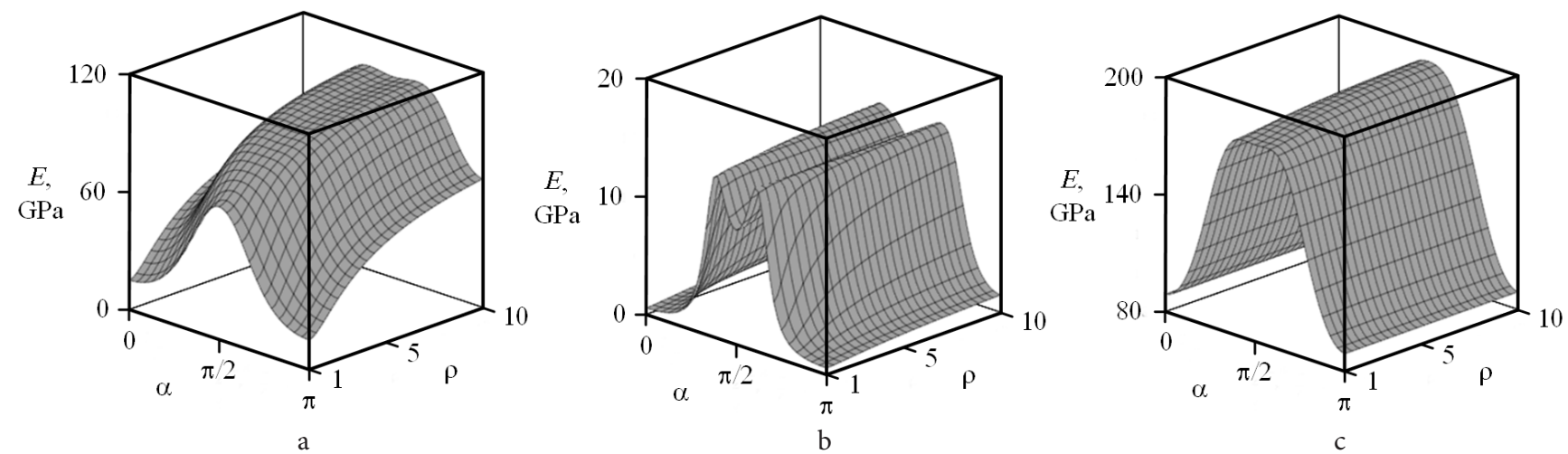

Fig. 2. Young's modulus of tubes from crystals $\mathrm{LaNbO}_{4}(\mathrm{a}), \mathrm{CsH}_{2} \mathrm{PO}_{4}$ (b) and $\mathrm{SiO}_{2}$ (coesite) (c). 

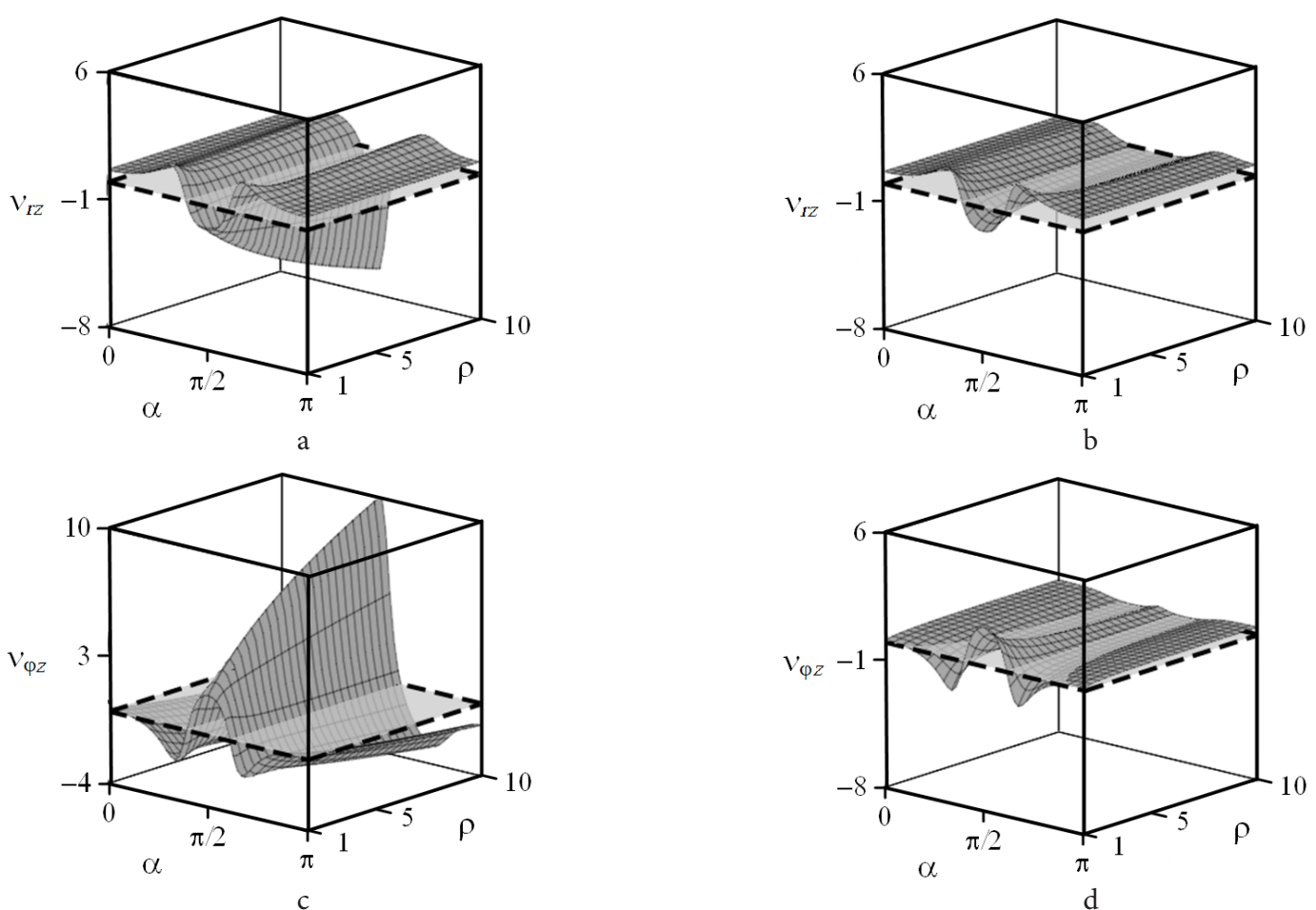

Fig. 3. Poisson's ratios $v_{r z}$ and $v_{\varphi z}$ for the inner $(\mathrm{a}, \mathrm{c})$ and the outer $(\mathrm{b}, \mathrm{d})$ surfaces of the tubes from $\mathrm{CsH}_{2} \mathrm{PO}_{4}$ crystal.

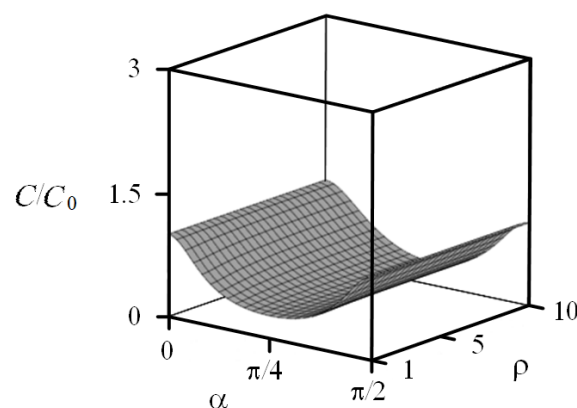

a

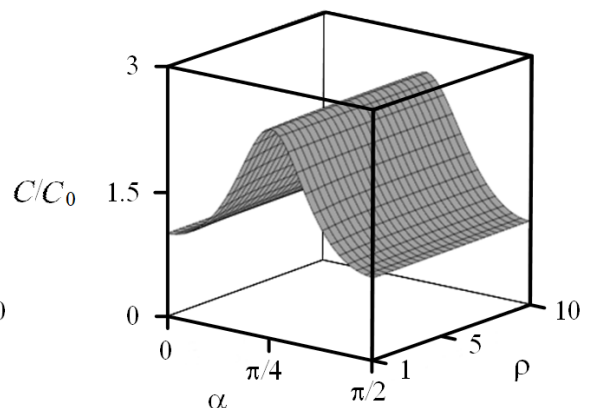

$\mathrm{b}$

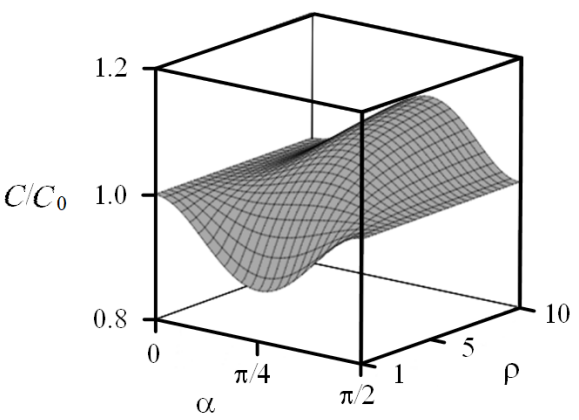

c

Fig. 4. The relative torsional stiffness of tubes from crystals $\mathrm{C}_{12} \mathrm{H}_{10}(\mathrm{a}), \mathrm{C}_{6} \mathrm{H}_{14} \mathrm{~N}_{2} \mathrm{O}_{6}(\mathrm{~b})$ and $\mathrm{Na}_{2} \mathrm{~S}_{2} \mathrm{O}_{3} \cdot 5 \mathrm{H}_{2} \mathrm{O}$ (c).

Table 4. Extreme values of the relative torsional stiffness of some tubes from monoclinic crystal when $1.01 \leq \rho \leq 10$ and $0 \leq \alpha \leq \pi / 2$.

\begin{tabular}{|c|c|c|}
\hline Tube & $C / C_{0 \min }$ & $C / C_{0 \max }$ \\
\hline $\mathrm{A}-\mathrm{TCNB}$ & 1 & 3.28 \\
\hline $\mathrm{C}_{12} \mathrm{H}_{10}$ & 0.27 & 1 \\
\hline $\mathrm{CsH}_{2} \mathrm{PO}_{4}$ & 0.05 & 1 \\
\hline Durene & 0.11 & 1 \\
\hline $\mathrm{C}_{6} \mathrm{H}_{14} \mathrm{~N}_{2} \mathrm{O}_{6}$ & 1 & 2.53 \\
\hline $\mathrm{LaNbO}_{4}$ & 0.39 & 1 \\
\hline$(\mathrm{COOH})_{2} \cdot 2 \mathrm{H}_{2} \mathrm{O}$ & 0.33 & 1 \\
\hline $\mathrm{KHCO}$ & 1 & 5.12 \\
\hline
\end{tabular}

chiral monoclinic tubes: the $C / C_{0}$ ratio monotonously increases (decreases) until an extremum is reached when $\alpha$ is close to $\pi / 4$ at small values of the thickness parameter. For most tubes, it persists with increasing thickness. One of the exceptions is a tube from $\mathrm{Na}_{2} \mathrm{~S}_{2} \mathrm{O}_{3} \cdot 5 \mathrm{H}_{2} \mathrm{O}$ crystal (Fig. 4c). The relative torsional stiffness of this tube decreases with $\rho<2.5$ as the angle of chirality changes from 0 to $\pi / 4$ and increases with $\rho>3.5$. At $2.5<\rho<3.5$, this tube has two $C / C_{0}$ extrema.

\section{Conclusion}

The analysis of variability of the Young's modulus, Poisson's ratios and relative torsional stiffness was carried out on the basis of experimental values of elastic coefficients from the handbook [10] with use of solutions of problems of torsion and extension of cylindrically anisotropic tubes. It is shown that such parameters as the chiral angle and the relative thickness of the tube walls can have a significant effect on the values of the Young's modulus, Poisson's ratio and torsional stiffness. In particular, due to a change in the chiral angle, the Young's modulus and the relative torsional stiffness of the tube can vary by more than two times. Poisson's ratios of chiral monoclinic tubes also have significant variability and can vary by several units in some cases. A number of auxetic thin-walled tubes have been identified, the majority of them have a negative angular Poisson's ratio of a significant value. Tubes from $\mathrm{CsH}_{2} \mathrm{PO}_{4}$ and $\mathrm{LaNbO}_{4}$ crystals are distinguished by large variability of the Young's modulus, Poisson's ratios and relative torsional stiffness. A tube from $\mathrm{Na}_{2} \mathrm{~S}_{2} \mathrm{O}_{3} \cdot 5 \mathrm{H}_{2} \mathrm{O}$ has nontypical behaviour in relative torsional stiffness. 
Aknowledgements. The study was supported by the Governmentprogram (contract\#AAAA-A17-117021310373-3).

\section{References}

1. A.E.H.Love. A Treatise on the Mathematical Theory of Elasticity. Cambridge, Cambridge Univ. Press (1927) 583 p.

2. R. Lakes. Science. 235, 1038 (1987). Crossref

3. K.E. Evans, B. D. Caddock. J. Phys. D. 22 (12), 1877 (1989). Crossref

4. P. S. Farrugia, J. N. Grima, R. Gatt. Phys. Status Solidi B. 245, 511 (2008). Crossref

5. K.W. Wojciechowski, A.C. Brańka, D. M. Heyes. Phys. Status Solidi B. 246 (9), 2063 (2009). Crossref

6. R. V. Goldstein, V.A. Gorodtsov, D. S. Lisovenko. Phys. Status Solidi B. 250 (10), 2038 (2013). Crossref

7. Z.A. D. Lethbridge, R.I. Walton, A.S. H. Marmier, C. W. Smith, K. E. Evans. Acta Mater. 58 (19), 6444 (2010). Crossref

8. M. A. Volkov. Letters on materials. 4 (3), 167 (2014) (in Russian) [M.А. Волков. Письма о материалах. 4 (3), 167 (2014).] Crossref
9. V.I. Erofeev, I. S. Pavlov. J. Appl. Mech. Tech. Phys. 56 (6), 1015 (2015). Crossref

10. Low frequency properties of dielectric crystals. LandoltBornstein: Numerical Data and Functional Relationships in Science and Technology Series. Ed. by D. F. Nelson Springer (1993). $\underline{\text { Crossref }}$

11. R.V. Goldstein, V.A. Gorodtsov, D.S. Lisovenko, M. A. Volkov. Phys. Mesomech. 17 (2), 97 (2014). Crossref

12. R. V. Goldstein, V.A. Gorodtsov, D. S. Lisovenko. Dokl. Phys. 58 (9), 400 (2013). Crossref

13. R. V. Goldstein, V.A. Gorodtsov, D.S. Lisovenko, M. A. Volkov. Phys. Status Solidi B. 252 (7), 1580 (2015). Crossref

14. R.V. Goldstein, V.A. Gorodtsov, D.S. Lisovenko, M. A. Volkov. Smart Mater. Struct. 25 (5), 054006 (2016). Crossref

15. M. Rovati. Scripta. Mater. 51 (11), 1087 (2004). Crossref 16. V. Ya. Prinz, V.A. Seleznev, V.A. Samoylov, A. K. Gutakovsky. Microelectron. Eng. 30 (1), 439 (1996). Crossref

17. Y. Mei, A.A. Solovev, S. Sanchez, O.G. Schmidt. Chem. Soc. Rev. 40, 2109 (2011). Crossref 